\title{
Political Contestation in Global Production Networks
}

Forthcoming in Academy of Management Review (2007)

Special Topic Forum on International Management: Critique and New Directions

\author{
David L. Levy \\ Professor, Department of Management \\ University of Massachusetts, Boston \\ 100 Morrissey Blvd. \\ Boston, Massachusetts 02125 \\ David.Levy@umb.edu
}




\title{
Political Contestation in Global Production Networks
}

\begin{abstract}
This paper develops a critical framework on international management and production that draws from the literatures on global commodity chains and global production networks (GPNs), from institutional entrepreneurship, as well as from neo-Gramscian theory in international political economy. The framework views GPNs as integrated economic, political, and discursive systems, in which market and political power are intertwined. The framework highlights the contingent stability of GPNs as well as the potential for actors to engage politically in contestation and collaboration over system governance and the distribution of benefits. The framework offers a multidimensional and multi-level approach to understanding power relations, ideology, and value appropriation in GPNs. The framework is valuable for examining the intersection of GPNs with charged political and social issues such as sweatshops and incomes for coffee growers, and the role of geography as a source of stability and tension in these networks.
\end{abstract}




\section{Political Contestation in Global Production Networks}

When you drink a cup of coffee, you are completing the final link in a global chain of activities that made that cup of coffee possible... That simple act of sipping your coffee connects you to peasant farmers in Colombia and Indonesia, to dockworkers in São Paulo and Mombassa, New Orleans and San Francisco, and to many others in between (Talbot, 2004: 1).

Multinational corporations (MNCs) face increasing pressure to engage with social issues related to their international operations. The pharmaceutical industry, for example, has been forced to accept the manufacture of generic drugs for AIDS/HIV in developing countries (Sell \& Prakash, 2004; Vachani \& Smith, 2004). Coffee processors and retailers have been challenged over the low prices paid to growers in some Latin American countries (Blowfield, 2004; Kolk, 2005; Talbot, 2004). Manufacturers of genetically modified organisms (GMOs) face a host of activist campaigns and are subject to an international agreement that regulates trade in these products (Andrée, 2005). Branded clothing companies have confronted numerous allegations of running 'sweatshops' in developing countries (Boje, 1998; Tulder \& Kolk, 2001). These cases exemplify the entanglement of global production networks (GPNs) with charged social and political issues. GPNs are thus characterized by contestation as well as collaboration among multiple actors, including firms, state and international agencies, non-governmental organizations (NGOs), and industry associations, each with their own interests and agendas. GPNs are therefore not simply arenas for market competition or chains of value-adding activities, but rather comprise complex political-economic systems in which markets, and their associated distribution of resources and authority, are constructed within, as well as actively shape, their socio-political context.

A useful starting point for analyzing GPNs can be drawn from Gereffi’s (1994: 2) description of ‘Global Commodity Chains’ (GCCs) as “sets of interorganizational networks 
clustered around one commodity or product, linking households, enterprises, and states to one another within the world-economy. These networks are situationally specific, socially constructed, and locally integrated, underscoring the social embeddedness of economic organization.” A number of scholars prefer the phrase ‘Global Production Networks’ (Dicken, 2003; Ernst \& Ravenhill, 1999; Henderson, Dicken, Hess, Coe, \& Yeung, 2002) because the term 'network' implies multiple relational forms and directions and avoids the linear connotation of ‘chains', while ‘production' is intended to convey not just economic activity but also “the social processes involved in producing goods and services and reproducing knowledge, capital and labour power” (Henderson et al., 2002: 444). It also avoids potential confusion in the use of the term 'commodity', which is often used to refer to undifferentiated, low margin products. GPNs entail the disaggregation and dispersion of economic activities to multiple geographic locations. This dispersion in turn requires a high degree of coordination and integration of supply chain activities, which often draws on the organizational capacity and geographic reach of MNCs and entails substantial foreign direct investment (FDI) and international trade (Caves, 1996; Ruigrok \& van Tulder, 1995). In many cases, such as ‘sweatshop' allegations and high prices for AIDS drugs, it is precisely the linkages created by GPNs across disparate regions with vastly different incomes, labor practices, and consumption patterns that give rise to contentious social concerns. On account of their economic and political character, GPNs are subject to complex forms of governance at multiple levels. Governance is defined broadly here to mean the rules, institutions, and norms that channel and constrain economic activity and its impacts. It therefore includes not only national level regulation and formal international agreements, but also the coordination of supply chains and the promulgation of private codes of conduct regarding labor or environmental standards (Cutler, Hauffler, and 
Porter, 1999; Gereffi, Humphrey, \& Sturgeon, 2005; Levy \& Newell, 2005; Prakash \& Hart, 1999).

This paper develops a critical framework on international management and production that analyzes the intersection of geographically dispersed economic networks with controversial social issues. Drawing from literatures on institutional theory and entrepreneurship, global commodity chains and global production networks, and neo-Gramscian approaches to international political economy, the paper proposes that GPNs are simultaneously economic and political phenomena. The framework is illustrated using a range of empirical examples, but with a focus on the coffee sector. The paper unfolds in the following manner. The remainder of the introduction introduces key concepts and outlines the core argument. The paper then presents a brief critique of conventional interpretations of international production, followed by an elaboration of the three theoretical approaches employed here to develop an understanding of GPNs as integrated economic-political systems. The articulation of these three theoretical approaches provides a multi-level perspective that yields a number of insights into the relationship between material and discursive dimensions of GPNs, the dynamic processes by which they are constituted and challenged, and their interaction with wider structures of power. A sociological perspective on markets suggests their embeddedness within wider social and political institutions (Callon, 1998; Granovetter, 1985; Lounsbury \& Ventresca, 2002), and the construction of managerial roles and consumer identities within this larger system (Olds \& Thrift, 2005). The economic structures of GPNs, represented, for example, in the lack of market power of developing country coffee growers or garment workers, tend to reflect broader geopolitical, ethnic, and gender power structures. Yet the GPN framework developed in this paper also pays attention to the agency of actors in mobilizing and deploying resources, forging 
alliances, shaping regulatory structures, and framing issues. From this perspective, GPNs resemble contested organizational fields in which actors struggle over the construction of economic relationships, governance structures, institutional rules and norms, and discursive frames (Hardy \& Phillips, 1998; Maguire, Hardy, \& Lawrence, 2004; Rao, Morrill, Zald, 2000). These efforts of 'institutional entrepreneurs' to change fields are frequently met with resistance from “field dominants", defined by McAdam and Scott (2005: 17) as "those individuals, groups, and organizations around whose actions and interests the field tends to revolve.”

The concept of a field derives from institutional theory's attention to the behavior of organizations within interrelated networks. According to Rao et al. (2000: 251), “Organizational fields....consist of regulatory agencies, professional societies, consumers, suppliers, and organizations that produce similar goods and services", and these fields "exhibit distinctive 'rules of the game', relational networks, and resource distributions.” Institutional theory has traditionally sought to explain convergence and stability in fields in terms of regulative, cognitive, and normative isomorphic forces (Powell \& DiMaggio, 1991; Scott \& Meyer, 1994). More recently, institutional theorists have emphasized the conflictual nature of contestation among actors over field structures and processes (Fligstein, 1997; Hardy \& Phillips, 1998; Levy \& Rothenberg, 2002; Maguire et al., 2004; Rao et al., 2000). Hoffman’s (1999: 352) analysis of competing environmental practices and discursive framings in the chemical industry highlights how "field constituents are often armed with opposing perspectives rather than with common rhetorics. The process may more resemble institutional war than isomorphic dialogue.” While GPNs constitute social institutions, they also have an important material dimension. Recent theoretical and empirical work on global commodity chains and production networks is valuable in illuminating the inequalities that stem from asymmetric power relations 
across firms and regions, recasting value chains as systems of value appropriation as much as creation (Gereffi \& Korzeniewicz, 1994; Henderson et al., 2002). This stream of research is valuable in highlighting a political dimension of market power, though it tends to take a rather economistic approach to power relations in value chains, focusing on the construction and protection of monopolistic advantages that generate high margins, or 'economic rent', while neglecting wider institutions of power. The present framework addresses these shortcomings by drawing from the growing literature that extends Gramscian theory to consider the nature of power and ideology in structures of international governance (Cox, 1987; Gill, 1993; van der Pijl, 1998). The neo-Gramscian approach is particularly useful for understanding the dialectical manner in which GPNs are shaped by, yet constitutive of, the broader context of neoliberal ideologies and institutions, geopolitical inter-state structures, and patriarchal gender relations. The Gramscian concept of hegemony offers a rich theoretical perspective on the configuration of economic, organizational, and discursive forces that stabilize and structure GPNs, and the nature of consent within these systems. Moreover, a Gramscian understanding suggests the potential and limitations of strategies for challenging and changing GPNs, and the intertwined political and economic character of these challenges.

It is hardly novel, of course, to observe that the globalization of production entails an international division of labor that reflects and reproduces class, gender, and ethnic inequalities (Fernandez-Kelly, 1994; Frobel, Heinrichs, \& Kreye, 1977). In developing countries in particular, the repression of unions (Boje, 1998) intersects with patriarchy (Calás \& Smircich, 1993) and geopolitical relations in the constitution of conducive nodes within GPNs (Enloe, 1989). Fuentes and Ehrenreich (1983) used the term 'global factory' to suggest the mobilization and integration of these power asymmetries into capitalist production. The conceptual framework 
developed here is innovative in the way it synthesizes and extends concepts from the three theoretical streams to understand the integrated economic, political, and discursive dimensions of GPNs. The international dispersion of GPNs masks asymmetries of power and income to some extent, but also creates opportunities for strategic agents to reveal these asymmetries, find points of tension and leverage, and challenge their structures and processes. McAdam and Scott (2005: 17) describe challengers as "those individuals, groups and organizations seeking to challenge the advantaged position of dominants or fundamental structural-procedural features of the field.”

These challenges generally entail economic, political, and discursive strategies, mirroring the elements of structural stability. However, even when challenger groups achieve some significant impact, such as the development of industry codes of conduct, the process of corporate accommodation frequently reinforces the legitimacy, and hence the political and market positioning of dominant firms. This dynamic process of contestation and accommodation casts new light on corporate social responsibility debates.

\section{Conventional Perspectives on International Production and Management}

The political understanding of GPNs proposed in this paper contrasts with conventional approaches to international production, which revolve around economistic considerations of location-specific advantages, such as factor costs and market access, and firm-specific advantages, such as technological or marketing expertise. These advantages are not static endowments, but rather dynamic capacities that accumulate at the firm and regional cluster level (Doeringer \& Terkla, 1995; Porter, 1990; Shaver \& Flyer, 2000). Within this framework, high transaction costs for intangible and transaction-specific assets would lead multinational corporations to internalize markets for them and directly control overseas operations (Buckley \& 
Casson, 1976; Dunning, 1988; Teece, 1986). MNCs are frequently conceived as overcoming barriers to trade through their ability to coordinate flows of goods, money, information, and people around the globe (Caves, 1996; Eden, 1991). MNCs can employ FDI as a substitute or as a complement for domestic production and exports (Kotabe, 1992; Salomon \& Shaver, 2005).

By the mid-1980s, production processes were increasingly being decomposed into constituent activities and dispersed to disparate geographic locations. Porter's (1985) conception of the 'value chain' became widely adopted as a conceptual framework for considering the linked set of economic activities that 'add value' at every stage, from research and development to final assembly and marketing. The task for managers in this framework is to construct the value chain so that activities are dispersed to appropriate locations in terms of proximity to markets, production costs, and resource availability (Buckley \& Ghauri, 2004; Kotabe \& Swan, 1994; Swamidass \& Kotabe, 1993). At the same time, value chains require coordination and integration in order to take advantage of scale economies, learning opportunities, and the benefits of integrated logistics and lean production (Bartlett \& Ghoshal, 1989; Levy, 1997). The central challenge of international business is seen as balancing the sometimes conflicting pressures for local responsiveness and for global integration (Bartlett \& Ghoshal, 1989; Prahalad \& Doz, 1987).

The increasing fragmentation of international production is driven by a series of economic, technological, organizational, and political factors. The emerging digital telecommunications infrastructure affords a dramatic increase in capacity and function at sharply lower costs, reducing the transaction costs of coordinating dispersed operations and facilitating trade in engineering, medical, legal, and other services. Since the collapse of the Soviet Union in 1991, a broad liberalization trend has brought policies that favor foreign investment, exports, and 
unrestricted capital flows (Dunning, 1993; Henderson et al., 2002). Developing countries, especially China and India, have created significant regional advantages based not just on lowcosts but also on technical expertise and growing firm-level capabilities (Friedman, 2005). Large firms have also augmented their capacity for coordinating dispersed networks by developing new organizational practices and more modular production processes that rely on standards and routinized interfaces with suppliers and customers (Ernst, 2000; Ernst \& Ravenhill, 1999). As Buckley and Ghauri (2004: 83) put it:

The managers of MNEs are increasingly able to segment their activities and to seek the optimal location for increasingly specialised slivers of activity. This ability to separate and relocate stages of production has led to a boom in manufacturing in China and service activities (e.g. call centres) in India. MNEs are also increasingly able to coordinate these activities by means of a wide variety of mechanisms from wholly owned FDI through licensing and subcontracting to market relationships. The more precise use of location and ownership strategies by MNEs is the very essence of increasing globalisation.

Conventional theories thus view the growth of international production and its specific configuration to be a result of economic forces that promote efficiency and value creation. Firms are viewed as efficiency-seeking agents, the organizational incarnations of more abstract phenomena such as comparative advantage. If international production is increasingly taking place within networks of subcontractors that are coordinated by dominant firms without direct ownership ties, then this is viewed as a market response to the lower costs of inter-firm relative to intra-firm coordination (Ernst, 2000). According to Henderson (2002: 444), "the GPN is seen to supersede the transnational corporation as the most effective form of industrial organization."

There is little doubt that economic forces play a central role in structuring GPNs, or that the growth in various forms of international production has contributed to rising output and incomes, at least in certain regions and particular sectors of the population. The problem is that purely economic accounts offer an inadequate portrayal of the complex ways in which market 
forces themselves operate within social and political contexts, as well as shape those contexts. An undue emphasis on efficiency, at the expense of concerns with equity or power, is closely tied to the broader ideology of free trade and a neoliberal discourse promoting the benefits of privatization and globalization (Gill \& Law, 1993).

Emblematic of this approach is a recent series of articles on offshore sourcing published in the influential journal of McKinsey, the management consulting firm. Agrawal and Farrell (2003: 37) argue in The McKinsey Quarterly that “companies move their business services offshore because they can make more money—which means that wealth is created for the United States as well as for the country receiving the jobs.” According to Agrawal and Farrell's analysis (2003: 41), “For every dollar of spending on business services that moves offshore, US companies save 58 cents, mainly in wages" and these lower costs constitute "by far the greatest source of value creation for the US economy.” In a critique of the McKinsey article, Levy (2005: 689) draws attention to the ideological assumptions embedded in the argument: "Wealth transfer is equated with wealth creation, corporate interests are conflated with those of society as a whole, and the process is portrayed as natural and inevitable, leading to prosperity for industrialized and developing countries alike.” Reducing wages does not 'create value', even in narrow economistic terms, though it certainly does transfer wealth from workers to shareholders.

This optimistic rendition of international production is far from uncontested. Indeed, there has been a resurgence of popular discontent and academic debate concerning every facet of globalization, from its impact on employment, inequality, and development (Korten, 1995; Narula \& Dunning, 2000) to its social and cultural significance (Bauman, 1998; Castells, 1997; Lash \& Urry, 1994). While some have argued that globalization increases the power of MNCs and renders states increasingly powerless and irrelevant (Griffen, 2003; Ohmae, 1991; Strange, 
1996), others assert that while economic integration might undermine traditional notions of sovereignty, it transforms the role of states and the nature and locus of governance (Braithwaite \& Drahos, 2000; Carnoy \& Castells, 2001; Held \& McGrew, 1993; Sassen, 1996). There have been significant challenges to the very idea of globalization, with some claiming that MNCs still retain a strongly national character and that the extent of global integration is neither unprecedented nor irreversible (Berger \& Dore, 1996; Hirst \& Thompson, 1996; Pauly \& Reich, 1997). This perspective has led some to interpret globalization as a discursive construction that promotes the importance of pursuing 'competitiveness' and serves to discipline firms, labor, and governments (Cerny, 1997; Piven \& Cloward, 1997; Ruigrok \& van Tulder, 1995: 169).

These debates, for the most part, have occurred amongst scholars of sociology, economic geography, and international political economy. Within international business, the bargaining theory of foreign direct investment proposes that the distribution of benefits between MNCs and host countries is a function of the bargaining power of the parties (Fagre \& Wells, 1982; Vernon, 1977). While this opens the door to a consideration of distributional impacts, the dominant view is that power shifts in favor of host countries over time. Moreover, bargaining theory does not address the presence of multiple actors in contested issue arenas. It has a narrow focus on economic sources of power, and it assumes that states act in the general interest, neglecting class, ethnic, and gender divisions, or potential alliances between the state and foreign capital (Evans, 1979; Gereffi, 1985; Levy \& Prakesh, 2003; Ramamurti, 2001).

Controversial issues in international business have received considerable scrutiny from the perspective of business ethics and corporate social responsibility (CSR). Working conditions in subcontractors of famous brand-name shoe and apparel firms such as Nike or The Gap, many of which are based in developing countries, provide one prominent example (Boje, 1998; Radin, 
2004; Tulder \& Kolk, 2001). More recently, a growing literature on 'ethical sourcing' has drawn attention to the low prices paid to coffee growers in relation to the premium prices charged by stores such as Starbucks (Blowfield, 2004; Kolk, 2005). Ethics and CSR perspectives have tended to view corporate practices, prices, and working conditions as matters of managerial discretion rather than an outcome of production networks as economic, political, and ideological systems.

The coffee case illustrates the economic, political, and ideological context in which GPNs are embedded. Coffee growers in developing countries are paid an average of about 50 cents per pound of coffee exported, though many growers only receive 20-30 cents (Kolk, 2005; Talbot, 2004). While a substantial amount of coffee is grown by smallholders or co-ops, large plantations predominate in some regions with workers receiving a very small proportion of the coffee price. Various intermediaries in coffee growing countries, including buyers, exporters, and credit providers, take a significant slice of the value chain. By far the largest amount of 'value added' is realized in the major Western consumer markets, where coffee wholesales for around \$4 per pound and retailers such as Starbucks sell for about $\$ 10$, with specialty and organic coffees reaching $\$ 14$ a pound. Brewed liquid coffee sells for the equivalent of $\$ 60-100$ per pound. As Talbot (2004: 163) makes clear in his extensive study, the distribution of income along the chain is a function of "struggles over the structure of the commodity chain and the politics of its governance.” To understand the working conditions facing workers and smallholders, we need to examine the market power of branded multinational coffee roasters and retailers, the consumer culture that grants status to these brands, geopolitical relations between the United States, Latin America, and other regions, the system of ethnic, class, and gender relations in growing regions, the ideology of neoliberalism that underpins a faith in 'free 
markets', and the role of multilateral institutions such as the World Bank in promoting cash crop coffee exports from heavily indebted developing countries. Markets are clearly highly political constructs. ${ }^{1}$

\section{Global Production Networks as Contested Fields}

The political character of markets is the common denominator of the three theoretical lenses brought to bear in this paper. First, I draw from institutional theory to posit that global production networks, as a set of structured yet contested relations, resemble institutional fields. This perspective offers a number of theoretical insights into their constitution and possibilities for change. Fields are frequently conceived at the national level, though Scott (1994: 206) has argued that: "Organizations are in the same field if they take one another into account, regardless of the geographic propinquity. In this way, the field conception emphasizes the possible importance of distant, non-local connections among organizations.” Nevertheless, national institutional environments are quite distinct in their regulatory, cultural and normative aspects. As a result, organizations that span national borders, such as MNCs and some NGOs, are subject to divergent pressures at the level of national sub-units (Kostova \& Roth, 2002; Westney, 1993). Simultaneously, these organizations can be members of a common industry, creating convergent pressures. Indeed, 'issue arenas' such as biotechnology and sweatshops can be considered as fields with their own institutional infrastructure and norms at the international level (Levy \& Kolk, 2002).

GPNs comprise diverse types of organizations, often in quite different industries. For example, a coffee production network encompasses coffee growers in developing countries, multinational food processors, traders active in futures and options markets, and large-scale 
retailers. These corporate forms interact with other actors who are not directly part of the production chain, such as NGOs, government agencies, and international organizations. Indeed, actors might barely recognize their membership in a common network. Awareness of their identity within a common system grows as actors collaborate and compete over economic, regulatory, and ideological dimensions of the network. Hardy and Phillips (1998: 218) contend that fields "emerge as different organizations perceive themselves to be connected to common issues. They are not objective, predetermined structures, but processes of social construction and meaning creation, wherein social order is negotiated.” For example, NGOs have collaborated with coffee growers, processors, and retailers in establishing Fair Trade programs in which growers are paid higher rates for certified coffee that is marketed under the Fair Trade label to Western consumers for premium prices (Kolk, 2005). The Fair Trade campaign by NGOs such as Global Exchange and the Rainforest Alliance has stimulated awareness that coffee farmers and retailers are members of a system possessing important social and political dimensions. The campaign thus played a role in constructing and politicizing the GPN as a field in which corporate practices are linked economically and discursively to poor working conditions for growers in developing countries. This challenge to existing market relations has been countered by the coffee industry, which argues that the problem is oversupply on world markets rather than income distribution within the chain. This claim is framed within the broader ideology of free trade to suggest that any interference in the market will only exacerbate matters (Blowfield, 2004; Talbot, 2004).

Challenging existing field structures and practices, and attempting to construct new institutional forms is a political project led by institutional entrepreneurs (Fligstein, 1997; Hardy, Phillips, and Lawrence, 2003; Maguire et al., 2004). Social movement theory has been influential 
in suggesting the forms of agency, sources of power, and strategic repertoire available to them

(Fligstein, 1996; McAdam, McCarthy, \& Zald, 1996). As Rao et al. (2000: 240) put it:

We conceptualize the construction of new organizational forms as a political process in which social movements play a double-edged role: They de-institutionalize existing beliefs, norms, and values embodied in extant forms, and establish new forms that instantiate new beliefs, norms and values. Crucial in these processes are institutional entrepreneurs who lead efforts to identify political opportunities, frame issues and problems, and mobilize constituencies.

Hardy and Philips (1998: 219) point to three aspects of power that are important in these processes: formal authority, the control of critical resources, and discursive legitimacy.

Organization theorists, however, have tended to emphasize the social construction of fields and hence the importance of political contestation in the cognitive and normative realms (Maguire \& Hardy, 2006; Selsky, Spicer, Teicher, 2003). Research has therefore tended to focus on the efforts to advance competing frames in efforts to secure legitimacy and build coalitions (Hensmans, 2003; Lounsbury, Ventresca, \& Hirsch, 2003). The emphasis on discourse and framing strategies has tended to obscure other dimensions in which fields are ordered. In particular, GPNs are structured in the economic and technological realms, and are subject to governance structures capable of exerting regulatory and coercive authority. In the following section, the evolution of the concept of global production networks is elaborated, in order to examine more closely the nature of order and power within these specific types of fields.

\section{From Value Chains to Global Production Networks}

Stephen Hymer's groundbreaking theoretical work on foreign investment and MNCs is now recognized by international business scholars as an essential starting point for investigating the relationship between market and political power (Buckley, 2006; Pitelis, 2006). Hymer (1972, 1976) posited that MNCs possess unique firm-specific advantages that afford significant market 
power in oligopolistic industries through control of key technologies, brands, and distribution networks. Hymer was the first to recognize that MNCs are created when firms internalize markets for these advantages across national borders (Pitelis, 2006), and he shifted the frame of analysis for international production from finance to questions of control (Strange \& Newton, 2006).

Hymer (1979) later developed these insights into a radical political-economic perspective in which MNCs "would transplant their vertical power structures to the globe, creating a vertical division of power between ‘superior and inferior’ states, cities and indeed peoples” (Pitelis, 2006: 104). Hymer's analysis of MNCs within oligopolistic markets paralleled the development of critical macro-perspectives on trade and investment, particularly the dependency school (Amin, 1976; Evans, 1979) and world systems theory (Chase-Dunn \& Grimes, 1995; Wallerstein, 2004), which viewed relations between industrial and developing countries as fundamentally exploitative and conditioned on unequal terms of trade. Indeed, Hymer's work constitutes the micro-foundations of these unequal relations. Frobel et al. (1977) described the ensuing international inequalities in power and income as ‘The New International Division of Labor'. Feminist scholars drew attention to the way in which international capital was reorganizing along gendered as well as ethnic lines (Calás \& Smircich, 1993; Chang, 2000; Fuentes \& Ehrenreich, 1983), while more recent neo-colonialist analyses (Banerjee \& Linstead, 2001) argue that these asymmetric relationships are embedded in ideological systems that devalue non-western norms and knowledge.

Hymer's key insight was that market power is thoroughly imbricated with political power, at the sectoral and even firm level. The market power associated with firm-specific assets such as technology or market access bears some affinity to the concept of resource dependency 
as a source of power (Pfeffer \& Salancik, 1978). Hymer's treatment, however, relates the market power of particular firms to more structural features of a stratified global political economy in which Western states and firms occupy a privileged position. In this vein, Gereffi (1985) and Evans (1979) described how MNCs enhance their power through their market and technology strategies and their alliances with local political elites. Gereffi's contribution, which was framed as a rejoinder to the 'obsolescing bargain' approach to MNC-host country relations (Kobrin, 1987; Vernon, 1971), served as a critical bridge to the development of Gereffi's more recent work on Global Commodity Chains.

Hymer has been widely criticized for emphasizing power over efficiency-based explanations of MNCs (Teece, 2006). These critiques, however, elide the extent to which market power is intertwined with efficiency, so that value creation is inextricably entangled with value capture. Pitelis (2006: 107) points out that Penrose (1959) had earlier observed that firm-specific 'efficiency' advantages derived from innovation can constitute the basis for monopolistic power. A common denominator of contemporary strategy theory, from Porter’s (1985) ‘5-forces’ analysis of market structures to the resource based view (Barney, 1991) and recent writing on dynamic capabilities (Teece, Pisano, \& Shuen, 1997), is that firms only derive above-normal profits from advantages that are sheltered from imitation. Walmart, for example, has firmspecific efficiency advantages that it has leveraged into substantial market power over competitors and suppliers, but this power takes on more explicitly political dimensions when wielded over labor and government agencies (Lichtenstein, 2006).

Conventional analyses of market power do not treat the topic as inherently political. States do, of course, provide legal sanction for the protection of patents, copyrights, and other forms of intellectual property rights (IPRs), and MNCs have increasingly sought to extend and 
protect these IPRs through multilateral organizations such as the WTO (Sell \& Prakash, 2004). Mintzberg builds on the work of Pfeffer and Salancik (1978) to argue that firms are deeply involved in negotiating their external environments in order to build and protect market position, such that any distinction between the economic and the political "must be considered artificial" (Mintzberg, Ahlstrand, \& Lampel, 1998: 235). This confluence of economic and political power is illustrated in Hirsch’s (1975) classic study of the pharmaceutical industry, in which he argued that its superior profitability derived from effective management of the institutional environment, particularly product entry, pricing, patent protection, and media coverage. The development of instant coffee illuminates the political nature of market positioning and the difficulty in demarcating value creation from value capture. Instant coffee, initially developed by Swiss MNC Nestlé, is much more capital and technology intensive than regular coffee, creating barriers to entry for smaller companies from developing countries (Talbot, 2004: 35). When Brazilian companies attempted to enter the instant coffee market to increase their own 'value added' and export it in bulk to western coffee MNCs, the latter objected, despite attractive prices. The coffee majors understood that this was a struggle for power and control over the industry (2004: 140).

Global Commodity Chain analysis develops Hymer's earlier insights to examine the distribution of 'value added' and rent in a chain by analyzing the interaction of geographic and firm-specific advantages, the locational configuration of activities, the institutional context, and the governance structures that regulate and integrate dispersed operations (Bair, 2005; Gereffi \& Korzeniewicz, 1994; Hopkins \& Wallerstein, 1977). GCC analysis has provided a series of rich case studies of the dynamics by which firms build positions of market power and defend them in the face of relentless competitive pressures to commoditize products and services (Bair \& Gereffi, 2003). These studies, located in the context of the spatial and political structure of 
production activities, often highlight the constraints as well as opportunities facing developing countries as they engage with globalization processes (Kaplinsky, 2000).

GCC analysis has brought attention to the relationship between market power and network-level governance. Gereffi (1994) distinguishes between producer-driven chains, such as the automobile industry, in which manufacturers dominate network coordination and capture the lion's share of value, and buyer-driven chains, such as the clothing sector, in which companies derive substantial profits from strong brand names and distribution while orchestrating networks of low-margin subcontractors. Kaplinsky (2000) discusses three forms of chain governance, legislative (rule setting), judicial (rule enforcement) and executive (corporate management). These governance functions relate to logistics, technical standards, quality, and design.

The emphasis on networks rather than chains among those who prefer GPN terminology highlights the "intricate links - horizontal, diagonal, as well as vertical - forming multidimensional, multi-layered lattices of economic activity” (Henderson et al., 2002: 442). Ernst’s rendition of GPNs emphasizes modes of governance that facilitate technical coordination of spatially dispersed activity and facilitate the flow of tacit knowledge (Ernst, 2000; Ernst \& Ravenhill, 1999). For economic geographers, the GPN framework examines the dynamic linkages and institutionalized power relations that these networks create not just across economic space, but also across social and institutional contexts, at national, regional, and sub-national levels (Dicken, Kelly, Olds, \& Yeung, 2001). Overall, GPN methodology attempts to characterize:

the networks of firms involved in R\&D, design, production and marketing of a given product, and how these are organized globally and regionally; the distribution of corporate power within those networks, and changes therein; the significance of labour and the processes of value creation and transfer; the institutions - particularly government agencies, but also in some cases trade unions, employer associations and NGOs - that influence firm strategy in the particular locations absorbed into the 
production chain; and the implications of all of these for technological upgrading, valueadding and capturing, economic prosperity etc. (Henderson et al., 2002: 447).

Despite these lofty ambitions, most of the studies spawned by the GPN framework to date are, in practice, very similar to those generated using GCC analysis. Much of the discussion concerns market power and consequent rents due to firm-level expertise and skills in coordinating complex networks. Indeed, the GCC and GPN literatures display an increasingly developmental tone, discussing how firms in developing countries might 'upgrade' their capabilities and thus create and capture more ‘value’ locally (Kaplinsky, 2005). The GCC/GPN framework appears to be converging with more conventional approaches to competitiveness and losing touch with its more critical origins (Bair, 2005). The discussion of governance emphasizes economic coordination rather than political contestation or the broader institutions and discursive structures in which markets are embedded. Moreover, the ideologies that constitute and legitimate particular forms of governance, production and income distribution receive little attention. The neo-Gramscian approach to international relations provides a valuable theoretical framework for locating GPNs in this wider context, as well as for understanding the relationship between material and discursive dimensions of order and power within these fields.

\section{A Neo-Gramscian Approach to Global Production Networks}

Interest in Gramsci's writing ${ }^{2}$ has enjoyed a modest revival in recent years in the field of international political economy (Gill, 1993; Jessop, 2005; Murphy, 1998; van der Pijl, 1998) and, to a lesser degree, in the literature on social movements, organizational resistance, and global managerial networks (Barker, Johnson, \& Lavalette, 2001; Carroll \& Carson, 2003; Mumby, 1997; Sanbonmatsu, 2004). Here the term 'neo-Gramscian' is used to acknowledge that the conceptual framework presented here extends Gramsci's ideas beyond national class conflict to 
examine conflictual social issues in international arenas engaging business and other societal actors. A neo-Gramscian approach offers an integrative perspective on GPNs that takes account of both their economic structure and their institutional character as an amalgam of rules, norms, and taken-for-granted ideas and practices. The notion of hegemonic stability in GPNs illuminates the process by which actors grant consent, at least contingently, to a set of arrangements in which authority and rewards are distributed asymmetrically; the contingency of hegemony points to the potential for strategic agents to challenge GPNs and highlights the political character of ensuing contestation.

Gramsci conceived of society as a complex dynamic system of structures and forces operating at multiple levels. He used the term hegemony to refer to a condition of relative stability in this system, in which a dominant alliance, or 'historical bloc', would emerge. This historical bloc sustains its position through the coercive authority of the state, dominance in the economic realm, and the consensual legitimacy of civil society. A key Gramscian insight is that hegemony in capitalist democracies relies primarily on consensual processes that accommodate subordinate groups to some degree, through a measure of political and material compromise and by the dissemination of ideologies that convey a mutuality of interests. Hegemony thus entails:

not only a unison of economic and political aims, but also intellectual and moral unity...the development and expansion of the [dominant] group are conceived of, and presented, as being the motor force of a universal expansion...In other words, the dominant group is coordinated concretely with the general interests of the subordinate groups (Gramsci, 1971: 181).

The globalization of economic and political processes in recent decades has led a number of observers to posit the emergence of a "transnational capitalist class" (Sklair, 1998), composed of senior managers, professionals, academics, and state officials linked in a loose alliance and sharing a common ideology. Gill (1995: 400) uses the Gramscian term "transnational historical 
bloc" to describe this formation "with its nucleus largely comprising elements of the G-7 state apparatuses and transnational capital...and associated privileged workers and smaller firms.” An historical bloc possesses two closely related dimensions; first, it refers to the organizational structure of the system, comprising alliances and hierarchical relations among various actors; second, it relates to the specific alignment of material, organizational, and discursive formations that stabilize and reproduce relations of production, meaning, and power. An historical bloc is 'hegemonic' when the synchronization of its various elements achieves a degree of stability and consent grounded in the construction of common interests. It should be emphasized that this multilayered concept of hegemony is quite different from the traditional use of the term in international relations to refer to the power of dominant states (Keohane, 1984).

Some striking parallels are evident between the concept of hegemony and the isomorphic stability of institutional theory (Scott \& Meyer, 1994). Both view social order as contingent on a balance of the coercive pressure of rules and more consensual forces of norms, cognitive frames, and taken-for-granted ideas. Moreover, the process of constructing (or challenging) hegemony corresponds closely to the "political model of action in the organizational field" (Fligstein, 1997: 398) in organizational theory (see also Rao et al., 2000; Seo \& Creed, 2002). Fligstein points to the importance of actors maintaining an image of selflessness as they frame issues in ways that resonate with existing conceptions of interest in order to build wider coalitions. Similarly, Maguire et al. (2004: 658) argue that the key to success in constructing and changing fields "is the way in which institutional entrepreneurs connect their change projects to the activities and interests of other actors in a field, crafting their project to fit the conditions of the field itself.” The concept of hegemony enriches our understanding of institutional fields in several ways, however. First, the notion of hegemony as an interwoven material and discursive formation 
provides a healthy antidote to the tendency in institutional theory to neglect the role of the economic and technological realm. Second, it provides a more dynamic view of social reality as “a relation of forces in continuous motion and shift of equilibrium” (Gramsci, 1971: 172). Third, it emphasizes the political nature of the struggles to shape the economic, discursive, and organizational dimensions of a field.

Importantly, Gramsci's concept of hegemony illuminates why weaker groups might consent to participate in a GPN in which they have little influence over the 'rules of the game' and do not enjoy a 'fair share' of the benefits. Hegemony conveys a subtle balance of ideology that legitimates the outcomes of a system, substantive concessions to weaker groups, and a degree of economic and political coercion. Consent, then, does not mean that weaker groups are dupes suffering from a form of 'false consciousness', as has been alleged by some critics of the dominant ideology thesis (Abercrombie, Hill, \& Turner, 1980). Gramsci’s concept of ideology is not a rigid system of ideas imposed on people in conflict with a set of pre-constituted, objective interests; rather, ideology is a relatively coherent articulation of meaning, embodied in institutions, language, and practices, that constructs people's identities and interests, aligning them to some degree with the broader polity (Hall, 1986: 20; Laclau \& Mouffe, 1985: 67). Yet ideology is also partial and fragmented (Gramsci, 1971: 327; Mumby, 1997: 344), creating space for resistance. Consent thus rests on strategic acquiescence as much as ideological domination (Levy \& Egan, 2003; Przeworski \& Wallerstein, 1982).

Though much of Gramsci's analysis was situated at the national level (Germain \& Kenny, 1998), his writing indicates an appreciation that regional and national fields comprise subsystems within broader international governance structures with economic and ideological elements: "international relations intertwine with these internal relations of nation-states, 
creating new, unique and historically concrete combinations. A particular ideology, for instance, born in a highly developed country, is disseminated in less developed countries, impinging on the local interplay of combinations” (Gramsci 1971: 182). He also noted the emergence of "international public and private organizations that might be the shapeless and chaotic civil society of a larger, economically concrete social order, and that certainly promoted such an order — the League of Nation's economic agencies, the International Chamber of Commerce, the World Council of Churches, the ILO, and various international fraternal orders " (Murphy, 1998: 423).

Locating GPNs in the context of transnational hegemonic structures provides more insight into their constitution and struggles over their operation. Sklair (1997) argues that transnational industry groupings such as the Trans-Atlantic Business Dialogue play a strategic role in forging the infrastructure of an emerging transnational bloc. ${ }^{3}$ Cox (1987) describes the growth and coordination at a global level of economic structures, neoliberal and consumerist ideologies, and political institutions such as the World Trade Organization, which promulgate rules and align interests. At the center of this bloc, Cox argues, is a transnational managerial class, which, despite internal rivalries, displays an 'awareness of a common concern to maintain the system' (1987: 359):

Various institutions have performed the function of articulating strategies in this common concern: the Trilateral Commission, the OECD, the IMF, and the World Bank all serve as foci for generating the policy consensus for the maintenance and defense of the system...Prestigious business schools and international management training programs socialize new entrants to the values, lifestyles, language (in the sense of shared concepts, usages, and symbols), and business practices of the class.

Recent empirical work using network analysis (Carroll \& Carson, 2003: 47) found that "amid the persistence of national corporate power structures, the global policy groups fulfill an integrative function, bringing together corporate directors and capitalist interests from various 
quarters of the world-system's centre.” The dominant ideology of this transnational elite embodies a "neoliberal discourse of governance that stresses the efficiency, welfare, and freedom of the market, and self-actualisation through the process of consumption” (Gill, 1995: 401). This ideology is buttressed by panoptic surveillance mechanisms that impose financial discipline on states, companies, and individuals, from the monitoring of inflation rates and budget deficits to corporate and personal credit ratings (Lazonick \& O'Sullivan, 2000). Gill terms the integration of the structural power of capital with market and consumerist ideology "disciplinary neoliberalism”, which generates powerful pressures to intensify the commodification of labor, nature, and other aspects of life: "A remarkable feature of contemporary world society is how more and more aspects of everyday life in OECD nations have come to be premised upon or pervaded by market values, representations, technological innovation, the hyper-mobility of financial capital, and some types of information flows” (Gill, 1995: 409).

GPNs thus exist within the 'transnational space' that is constituted and structured by transnational elites, institutions, and ideologies (Faist, 2000; Morgan, 2001). Within this space, transnational communities emerge with economic systems, relations of power and institutional forms that are distinct from, though interact with, national or region-bound forms (Urry, 2000). For Morgan (2001: 118) these communities comprise transnational corporations, regulatory agencies, and cognitive and normative frameworks which "have to be conceptualized in terms of the interplay between top-down projects of transnationalism, pursued by powerful actors, and bottom-up processes of mutual identification and collective awareness.” Morgan (2001: 125) points to the crucial role of the business press and business schools in creating a sense of common identity and interests, a shared understanding of business practices, and providing points of access to transnational networks. Olds and Thrift (2005) use the term "cultural circuit 
of capital" to refer to the flows of knowledge, ideas, and values that bind together "global assemblages" of actors and economic practices. They note the "the role of business schools as the key nodes in this circuit” (2005: 272), alongside management consultancies and gurus, and they also point to the role of the media as "key means of transport, amplifiers, and generators of business knowledge” (2005: 274). Olds and Thrift argue that states are also mobilized within this cultural circuit of capital to assume the mantle of securing economic growth and national competitiveness, to which end they endeavor to produce "pliant but enterprising subjects" (2005: 275) with appropriate sets of skills and attitudes to succeed in highly competitive global labor markets. Policymakers and professionals at the state and regional level are thus accomplices in the rise of the 'competition state' (Cerny, 1997; Palan \& Abbott, 1996), whose primary goal is to improve ‘competitiveness’ and attract mobile investment (Stopford \& Strange, 1991).

The neo-Gramscian perspective on GPNs highlights dynamic struggles over governance and the relationship between technical features of the market with the wider political environment. Shifting regimes of GPN governance in the coffee case illustrate these processes. The International Coffee Agreement (ICA) in force from 1962 till 1972 established a regulated quota system in which growers received modestly higher, if more stable, prices. U.S. support for the agreement during these Cold War years has generally been attributed to the desire to create sufficient economic stability in Latin America to prevent the spread of Communism; indeed, the ICA was viewed as a disguised form of international aid. The American National Coffee Association, representing the large national coffee companies, shared these concerns and was willing to pay modestly higher prices for more secure and stable supply (Talbot, 2004: 58-60). The ICA lapsed in 1972, was renegotiated for a period, but finally collapsed in 1989, leading to a dramatic fall in coffee prices. One reason for this shift in governance structure was the growing 
market power of Western multinational coffee producers and retailers, due to consolidation and the growing importance of branded quality coffee. The position of growers was further weakened by significant additions to global supply, as a number of developing countries attempted to increase their cash crop exports, sometimes under the discipline of World Bank Structural Adjustment Programs. By the late 1990s, Vietnam had become the world's second largest coffee producer, surpassing Colombia. Under the these conditions, Western coffee MNCs could extend their control over the supply chain and gain access to plentiful supplies of cheap coffee without a restrictive international agreement.

Though the market-based coffee GPN of the 1990s conformed to the dominant neoliberal ideology, low prices and the dire poverty of growers created new tensions that NGOs were able to exploit, taking advantage of renewed popular concern with aspects of globalization. The development of Fair Trade practices and industry codes of conduct, such as the Common Code for the Coffee Community (4C), can be interpreted as a political effort to protect the hegemonic stability of the GPN from threats to its legitimacy. Industry development and implementation of these practices has transformed some NGOs from challengers to partners, widening the hegemonic coalition. Couched within the discourse of corporate social responsibility, which gained considerable discursive currency in the 1990s, the coffee industry's accommodation to pressure enables it to project moral and intellectual leadership and a sense of congruence between corporate goals and the general interest. This is, of course, the essence of hegemony.

\section{An Integrated Analytical Framework on Global Production Networks}

A synthesis of the three theoretical perspectives discussed above yields a framework that views GPNs as integrated economic, political, and discursive structures with a degree of structural 
stability, but subject to challenge by strategic actors. The following section draws out two significant implications, first, for the role of economic structures and processes in stabilizing fields and reproducing particular discursive forms, and second, for the potential for challengers to develop strategies to contest GPNs.

While scholarship on institutional theory and politically contested fields has paid considerable attention to the embeddedness of markets and technologies in social and discursive structures, it has neglected the role of the material realm in structuring the social. GCC/GPN analysis has brought attention to the importance of market power in the distribution of rent and governance, but has neglected discursive dimensions and wider structures of power. For Gramsci (1971: 161), "though hegemony is ethical-political, it must also be economic, must necessarily be based on the decisive function exercised by the leading group in the nucleus of economic activity.” Neo-Gramscian writers in international political economy have described how a globalizing economic system is accompanied by a legitimating set of neoliberal ideologies. These ideas and norms concerning the benefits of free trade, 'flexible' labor, and a fiscally restrained state, do not arise spontaneously in a deterministic relation to society's material 'base', but rather are developed and disseminated by dominant groups through policy, media, and educational channels, sometimes against considerable opposition (McChesney, 2000).

Most telling, perhaps, is when a change in material conditions triggers a shift in ideology. By the latter 1990s, there was increasing media concern about the economic impact of offshore sourcing of high 'value added' products and services and associated skilled employment (Kletzer, 2001; Levy, 2005). Free trade ideology had been firmly entrenched among policy and professional elites since the rise of the United Kingdom as a global economic power in the mid $19^{\text {th }}$ century, leading most economists and the financial press to respond with assurances that 
comparative advantage theory still applied, so that offshoring presents another opportunity for Americans to upgrade their skills even further (Swann, 2004). In 2004, however, the economist and Nobel laureate Paul Samuelson (2004) published a paper demonstrating that the United States would be hurt by trade with India and China if those countries improved their export performance in sectors traditionally dominated by the United States, such as software and aircraft manufacturing. The paper does not rely on any sophisticated new analysis and revisits ideas originally proposed in the 1970s; its appearance perhaps signals the opening of a fissure in the hegemonic free trade system.

Here we posit that material structures play an important role in stabilizing fields at the level of GPNs, by reproducing particular ideologies and by generating the economic incentives required to induce cooperation from a diverse set of actors. 'Business models' need to generate profits for firms, wages for labor, and result in sufficient demand from consumers. Of course, these business models are also shaped by the political economy of the network, through property rights and labor law, trade and tax policy, and subsidies, and companies frequently exert their economic power to influence these factors. The continued dominance of the fossil fuel industry, for example, is related not just to the low cost of these fuels, but to the power of the industry in securing large subsidies and lax environmental regulation (Goodell, 2006). Efforts to promote cleaner forms of energy and transportation have gained a degree of discursive legitimacy and are supported by a wide coalition of NGOs, government agencies, and even some companies in the 'clean energy’ sector. Nevertheless, these firms face substantial market barriers to entry and lack political access and influence. Moreover, the new technologies such as solar panels and fuel cells have not yet reached competitive cost and reliability levels; they are failing to 'cooperate', in the language of actor-network theory (Callon, 1987). 
In contested GPNs, industry often uses economic resources to pursue discursive strategies alongside other forms of political activity, thus building legitimating ideologies and governance structures to support particular economic arrangements. Awareness of commercial opportunities in biotechnology, for example, led entrepreneurial companies such as Monsanto to pursue public relations strategies to frame genetically modified (GM) seeds and foods as a benign extension of traditional methods of hybrid development that promise to improve yields and end hunger. Simultaneously, these companies worked in the political and legal sphere to secure property rights protection for GM products and to exempt them from the U.S. Food and Drug Administration approval process (Andrée, 2005). Similarly, companies in fossil-fuel related sectors facing the climate change issue have expended considerable resources to lobby against mandatory emission controls at the international level, while casting doubt on the science of climate change and emphasizing the high costs of action (Levy \& Egan, 2003).

Industry strategies frequently extend beyond a particular GPN to shape broader global institutional structures. Key service sectors were prominent architects of the agreement to extend the global trade regime to include services during the Uruguay round of the GATT (the precursor to the WTO) (Wesselius, 2002). Sell (2002) has amply documented the leading role of MNCs in the software, entertainment, and pharmaceutical industries in promoting the discourse of intellectual property rights and in actually drafting accords for Trade Related Aspects of Intellectual Property Rights (TRIPS), under the auspices of the World Trade Organization.

Hegemonic fields are subject to continuous stress due to the dynamics of evolving technologies, markets and ideologies. The dominance of neoliberalism, for example, does not remain unchallenged; transnational institutions such as the World Bank and WTO have to accommodate financial crises in Asia associated with deregulation of capital, the failures of 
water privatization in Latin America, and challenges from civil society to environmentally damaging infrastructure projects (Williams \& Ford, 1999). A neo-Gramscian perspective on contested GPNs highlights the multiple dimensions of hegemonic structures and the potential for subordinate groups to develop coordinated strategies that take advantage of tensions and points of leverage in a complex socio-economic system. Indeed, a crucial element of Gramsci’s break from the economic determinism associated with Marx was his elucidation of the "Modern Prince”, the embodiment of collective strategic action by those with scarce access to material resources or formal authority. Gramsci used the term 'war of position' to describe a long-term strategy coordinated across multiple bases of power to gain legitimacy, shift economic relations, develop organizational capacity, and win new allies; social movements trying to change practices and structures in GPNs can be considered to be contemporary expressions of the Modern Prince, using clever strategy to outmaneuver structural forms of power (Barker et al., 2001; Levy, Willmott, and Alvesson, 2003; Sanbonmatsu, 2004). This insight is echoed in the institutional entrepreneurship literature, which suggests that subordinate actors need to rely more heavily on skills than material resources (Fligstein, 1997; Maguire et al., 2004; Rao et al., 2000).

The effective deployment of strategic power requires a detailed analysis of GPN structures and processes. A GPN framework suggests that consumption of high-priced coffee and clothing brands and production by low-wage labor are intrinsically linked and mutually contingent. They are enabled by the intricate logistics of international production, yet they are also sustained by the economic, cultural, linguistic, ethnic, and legal distanciation involved. As Henderson (2002: 446) suggests, GPNs “constitute and are re-constituted by the economic, social and political arrangements of the places they inhabit.” The balance of coercion and consent varies across countries, leaning more toward coercion in authoritarian countries, thus requiring 
fewer concessions to labor and less elaborate forms of workplace control. The political sustainability of GPNs therefore depends, in part, on the insulating effect of distance between conditions of production and consumption. As Klein observes (2000: 347), “[i]t's as if the global production chain is based on the belief that workers in the South and consumers in the North will never figure out a way to communicate with each other.”

Activists have used these insights in their attempts to build discursive and organizational connections across the barriers of distance to highlight the contradictions within GPNs. Multinational corporations operating across national boundaries are particularly vulnerable because they provide "opportunities for interest groups to identify practices used by the firm in some country that may be unacceptable in another country and to use those as a rallying point” (Kostova \& Zaheer, 1999: 74). NGOs engaged in a campaign against GM foods have explicitly used an understanding of the supply chain structure to target vulnerable food retailer chains in Europe, several of whom adopted GM-free policies (Schurman, 2004). In the clothing sector, student activists and labor groups developed alliances with religious organizations and targeted companies whose well-known brands make them particularly exposed to embarrassing disclosures. Activists have also successfully exerted pressure on U.S. universities with large sportswear contracts, leveraging public visibility and concentrated purchasing power (van Tulder \& Kolk, 2003). NGOs found accounting firms to be unlikely allies interested in developing the business of auditing social reports and compliance with codes of conduct.

Hegemonic systems are resilient to challenge, however, and tend to absorb and deflect threats in ways that protect system fundamentals. Indeed, the long-term nature of a 'war of position' makes it difficult to evaluate the success of challenger strategies at a given point in time. Although some look optimistically to NGOs as a democratic force for change, representing the interests of labor, women, and the environment (Teegen, Doh, \& Vachani, 2004), a 
Gramscian analysis suggests that civil society represents not only an arena of ideological struggle, but also a key element of the 'extended state' in which hegemony is secured.

NGOs active in the coffee case have clearly made some significant gains; they have created an awareness of coffee as a political and social issue, pressured many of the coffee MNCs to adopt the '4C' code of conduct, and they have helped to develop a market for Fair Trade and organic coffee that substantially raises incomes for at least some growers and eliminates some of the middlemen in the value chain. Yet these gains have not changed the core asymmetries of power and income in the coffee GPN, and have perhaps even strengthened the position of Western MNCs. The 4C code of conduct addresses the worst forms of corporate practice, such as the use of bonded and forced labor, peasant eviction, access to potable water for workers, and the use of banned pesticides (Kolk, 2005). It does not, however, touch structural features of the GPN that influence income distribution. Fair Trade and organic coffee do not comprise more than $1 \%$ of the global market (Talbot, 2004), offering just a few niche market opportunities for growers and highlighting the limitations of strategies that rely on sociallymotivated purchasing decisions by affluent Western consumers (Utting, 2002). Meanwhile, participation in these programs rewards coffee MNCs with stronger brand images and greater legitimacy; Starbucks, for example, benefits from the publicity it received when it announced in 2001 a commitment to buy one million pounds of Fair Trade coffee over the following eighteen months, though this is less than $2 \%$ of its total coffee purchases. Growers excluded from the premium coffee segment find their position with commodity coffee is weaker than ever. 


\section{Conclusions and Implications}

This paper has developed a critical reconceptualization of international production by linking the analysis of global production networks with the literatures on institutional entrepreneurship and neo-Gramscian theory in international political economy. The result is a framework that provides insights into the nature of power and hegemony in a global production network, encompassing the dynamics of contestation and stability as actors employ economic, discursive, and organizational strategies. The framework is particularly valuable in perceiving GPNs as, at once, technically and organizationally sophisticated production networks, and as political systems encompassing multiple dimensions of power. While more conventional treatments drawing from commodity chain analysis focus on relations of market power among firms, here we consider GPNs in the context of wider institutional, political, and discursive structures, as well as linkages with NGOs and other actors usually considered to be external to GPNs.

The institutional entrepreneurship literature is valuable in furthering our understanding of GPNs as contested fields in which actors develop a consciousness of their identities and interests, and forge strategies to mobilize resources, build alliances, and frame issues in particular ways. The neo-Gramscian approach adds to this conception in several ways. It offers an appreciation of the multi-level dynamic interactions between GPNs and broader, more entrenched hegemonic formations in the global political economy. It also offers theoretical linkages between the configuration of material, ideological, and organizational forces comprising hegemonic stability and contingency, and the strategies actors pursue to protect or challenge field formations. In particular, it suggests how actors who are relatively disadvantaged in terms of material resources 
or formal authority can utilize smart strategy that takes advantage of fragile alliances or tensions within and between the economic and discursive spheres.

At the same time, the multi-level and resilient nature of hegemony points to the limitations of strategic action for change. Dominant actors frequently respond to pressure from challengers with counter-strategies that entail a degree of local accommodation and compromise around a specific issue, but in a way that preserves the essentials of a field structure, and in some cases even reinforces their position. The ongoing and dynamic evolution of these fields suggests that it is difficult, at least in the short run, to distinguish between reformist strategies that lead to cooptation of challengers and the blunting of efforts for more systemic change, and long-term dynamic strategies that use the shifting terrain of compromise as the staging ground for another round of contestation.

The concept of hegemony as contingent stability in an evolving, contested field, helps illuminate the coexistence of apparently contradictory trends in the global economy. On the one hand, companies are undertaking a plethora of initiatives under the mantle of corporate social responsibility, from annual social reports to the promulgation of codes of conduct. On the other hand, inequality is rising in many Western countries as workers suffer from weakened unions, loss of state provision of services, and increased competition from offshore sourcing and laborsaving technologies. Neoliberal institutions and ideologies appear to remain well entrenched; indeed, the strengthening and extension of intellectual property rights in relation to software, biotechnology, entertainment, and pharmaceuticals suggests a strengthening of the market power of MNCs in these sectors and a deepening process of commodification. These contradictory trends can be understood as manifestations of a shifting balance of forces as actors engage in 
strategies and counter-strategies at multiple levels across a complex economic and discursive terrain.

While GCC/GPN analysis is centrally concerned with the relationship between high profit margins and market power, it has not developed a more fundamental critique of the terms 'value-added' and 'value chain' and their ideological connotations. Indeed, these terms confer discursive legitimacy by emphasizing collaboration in the generation of wealth rather than conflicts over its distribution. The framework developed here renders problematic the entire conception of 'value-added', and suggests that relations of power are associated with inequalities in value appropriation. The managerial imperative to create and capture 'value' is inextricably linked to the rise since the 1980s of 'shareholder value' as a mode of corporate governance that emphasizes 'financialization' of corporate objectives to meet capital market expectations and appease mutual fund managers (Williams, 2000). The primacy of shareholder value and the subjugation of production to financial market discipline is not necessarily congruent with sustainable economic prosperity (Lazonick \& O'Sullivan, 2000) nor with the well-being of a broader range of stakeholders (Hillman \& Keim, 2001). Market power needs to be contextualized within broader cultural and political institutions that constitute the social value of brands and legitimate and enforce intellectual property rights.

One implication of viewing markets within institutional and ideological contexts is that they are not the abstract, ahistorical constructions of economic theory; they can never be 'free'. The coffee case in this paper illustrates how GPN governance transitioned from a system based on price and quantity regulation within a formal international agreement, to one that, ostensibly at least, is more market based. This market, however, has been shaped and conditioned by the struggle for control between coffee MNCs and developing country growers, the excess supply 
induced by World Bank policies and export promotion in Vietnam and Brazil, the growth of premium and Fair Trade coffees, and industry self-regulation through codes of conduct. The market is not necessarily more 'free' under the new mode of governance; rather, it operates under a different matrix of forces and constraints. 


\section{REFERENCES}

Abercrombie, N., Hill, S., \& Turner, B. S. 1980. The dominant ideology thesis. London: Allen and Unwin.

Agrawal, V., \& Farrell, D. 2003. Who wins in offshoring. The McKinsey Quarterly, (4): 37-41. Amin, S. 1976. Unequal development. Hassocks: Harvester.

Andrée, P. 2005. The genetic engineering revolution in agriculture and food: strategies of the 'biotech bloc'. In D. L. Levy, \& P. J. Newell (Eds.), The business of global environmental governance: $135-168$. Cambridge, Mass.: MIT Press.

Bair, J. 2005. Global capitalism and commodity chains: Looking back, going forward. Competition and Change, 9: 153-180.

Bair, J., \& Gereffi, G. 2003. Upgrading, uneven development, and jobs in the North American apparel industry. Global Networks, 3: 143-169.

Banerjee, S. B., \& Linstead, S. 2001. Globalization, multiculturalism and other fictions: Colonialism for the new millennium? Organization, 8: 683-722.

Barker, C., Johnson, A., \& Lavalette, M. (Eds.). 2001. Leadership and social movements. Manchester: Manchester University Press.

Barney, J. 1991. Firm resources and sustained competitive advantage. Journal of Management, 17: 99-120.

Bartlett, C., \& Ghoshal, S. 1989. Managing across borders: The transnational solution. Boston: Harvard Business School Press.

Bauman, Z. 1998. Globalization: The human consequences. Cambridge: Polity.

Berger, S., \& Dore, R. (Eds.). 1996. National diversity and global capitalism. Ithaca: Cornell University Press.

Blowfield, M. 2004. Ethical supply chains in the cocoa, coffee and tea Industries. Greener Management International, 43: 15-24.

Boje, D. M. 1998. Nike, Greek goddess of victory or cruelty? Women's stories of Asian factory life. Journal of Organizational Change Management, 11: 461-480.

Braithwaite, J., \& Drahos, P. 2000. Global business regulation. Cambridge: Cambridge University Press.

Buckley, P. J. 2006. Stephen Hymer: Three phases, one approach? International Business Review, 15: 140-147.

Buckley, P. J., \& Casson, M. C. 1976. The future of multinational enterprise. London: Macmillan.

Buckley, P. J., \& Ghauri, P., N. 2004. Globalisation, economic geography and the strategy of multinational enterprises. Journal of International Business Studies, 35: 81-98.

Calás, M. B., \& Smircich, L. 1993. Dangerous liaisons: The "feminine-in-management" meets globalization. Business Horizons, 36: 164-180.

Callon, M. 1987. Society in the making: the study of technology as a tool for sociological analysis. In W. E. Bijker, T. P. Hughes, \& T. Pinch (Eds.), The social construction of technological systems: 83-103. Cambridge, Mass.: MIT Press.

Callon, M. 1998. The laws of the markets. Oxford: Blackwell.

Carnoy, M., \& Castells, M. 2001. Globalization, the knowledge society, and the Network State: Poulantzas at the millennium. Global Networks, 1: 1-18.

Carroll, W. K., \& Carson, C. 2003. The network of global corporations and policy groups: A structure for transnational capitalist class formation? Global Networks, 3: 29-57. 
Castells, M. 1997. The information age: Economy, society and culture. Volume II: The power of identity. Malden, MA: Blackwell.

Caves, R. E. 1996. Multinational enterprise and economic analysis (Second ed.). Cambridge: Cambridge University Press.

Cerny, P. G. 1997. Paradoxes of the competition state: The dynamics of political globalization. Government and opposition, 32: 251-274.

Chang, G. 2000. Disposable domestics: Immigrant women workers in the global economy. Cambridge, MA: South End Press.

Chase-Dunn, C., \& Grimes, P. 1995. World-Systems analysis. Annual Review of Sociology, 21: 387-417.

Cox, R. W. 1987. Production, power, and world order. New York: Columbia University Press.

Cutler, C. A., Haufler, V., \& Porter, T. (Eds.). 1999. Private authority and international affairs. Albany, NY: SUNY Press.

Dicken, P. 2003. Global production networks in Europe and East Asia: The automobile components industries, Manchester University, School of Environment and Development. GPN Working Paper 7. Manchester.

Dicken, P., Kelly, P. F., Olds, K., \& Yeung, H. 2001. Chains and networks, territories and scales: towards a relational framework for analysing the global economy. Global Networks, 1: 89-112.

Doeringer, P. B., \& Terkla, D. 1995. Business strategy and cross-industry clusters. Economic Development Quarterly, 9: 225-237.

Dunning, J. 1988. Explaining international production. Boston: Unwin Hyman.

Dunning, J. H. 1993. Governments and multinational enterprises: from confrontation to cooperation? In L. Eden, \& E. Potter (Eds.), Multinationals in the global political economy: 59-83. New York: St. Martins.

Eden, L. 1991. Bringing the firm back in: Multinationals in International Political Economy. Millennium: Journal of International Studies, 20: 197-224.

Enloe, C. 1989. Bananas, beaches, and bases: Making feminist sense of international politics. Berkeley, CA: University of California Press.

Ernst, D. 2000. Global production networks and the changing geography of innovation systems: implications for developing countries. East-West Centre Working Paper 9, Honolulu.

Ernst, D., \& Ravenhill, J. 1999. Globalization, convergence, and the transformation of international production networks in electronics in East Asia. Business and Politics, 1: 35-62.

Evans, P. 1979. Dependent development: The alliance of multinational, state, and local capital in Brazil. Princeton, New Jersey: Princeton University Press.

Fagre, N., \& Wells, L. T. 1982. Bargaining power of multinationals and host governments. Journal of International Business Studies, 13: 9-23.

Faist, T. 2000. The volume and dynamics of international migration and transnational social spaces. Oxford: Oxford University Press.

Fernandez-Kelly, M. P. 1994. Making sense of gender in the world economy: Focus on Latin America. Organization, 1: 249-275.

Fligstein, N. 1996. Markets as politics: a political cultural approach to market institutions. American Sociological Review, 61: 656-673.

Fligstein, N. 1997. Social skill and institutional theory. American Behavioral Scientist, 40: 397405. 
Friedman, T. L. 2005. The world is flat: A brief history of the twenty-first century. New York: Farrar, Straus and Giroux.

Frobel, F., Heinrichs, J., \& Kreye, O. 1977. The new international division of labor. Hamburg: Rowohlt Taschenbuch Verlag.

Fuentes, A., \& Ehrenreich, B. 1983. Women in the global factory. Boston, MA: South End Press.

Gereffi, G. 1985. The renegotiation of dependency and the limits of state autonomy in Mexico. In T. Moran (Ed.), Multinational corporations: The political economy of foreign direct investment: 83-106. Lexington, Mass.: D.C. Heath.

Gereffi, G. 1994. The organization of buyer-driven global commodity chains. In G. Gereffi, \& M. Korzeniewicz (Eds.), Commodity chains and global capitalism: 95-122. Westport, CT: Greenwood.

Gereffi, G., Humphrey, J., \& Sturgeon, T. 2005. The governance of global value chains. Review of International Political Economy, 12: 78-104.

Gereffi, G., \& Korzeniewicz, M. (Eds.). 1994. Commodity chains and global capitalism. Westport, CT: Praeger.

Germain, R. D., \& Kenny, M. 1998. Engaging Gramsci: International theory and the new Gramscians. Review of International Studies, 24: 3-21.

Gill, S. (Ed.). 1993. Gramsci, historical materialism and international relations. Cambridge: Cambridge University Press.

Gill, S. 1995. Globalisation, market civilisation, and disciplinary neoliberalism. Millenium: Journal of International Studies, 24: 399-423.

Gill, S., \& Law, D. 1993. Global hegemony and the structural power of capital. In S. Gill (Ed.), Gramsci, historical materialism and international relations: 93-124. Cambridge: Cambridge University Press.

Goodell, J. 2006. Big Coal: The dirty secret behind America's energy future. Boston, MA: Houghton Mifflin.

Gramsci, A. 1971. Selections from the prison notebooks (Q. Hoare, \& G. Nowell-Smith, Trans.). New York: International Publishers.

Granovetter, M. 1985. Economic action and social structure: the problem of embeddedness. American Journal of Sociology, 91: 481-510.

Griffen, K. 2003. Economic globalization and institutions of global governance. Development and Change, 34: 789-807.

Hall, S. 1986. Gramsci's relevance for the study of race and ethnicity. Journal of Communication Inquiry, 10 (2): 5-27.

Hardy, C., \& Phillips, N. 1998. Strategies of engagement: Lessons from the critical examination of collaboration and conflict in an interorganizational domain. Organization Science, 9: 217-230.

Hardy, C., Phillips, N., \& Lawrence, T. B. 2003. Resources, knowledge and influence: The organizational effects of interorganizational collaboration. Journal of Management Studies, 40: 321-347.

Hayek, F. (Ed.). 1944. The road to serfdom. Chicago: Chicago University Press.

Held, D., \& McGrew, A. 1993. Globalization and the liberal democratic state. Government and Opposition, 28: 261-285. 
Henderson, J., Dicken, P., Hess, M., Coe, N., \& Yeung, H. 2002. Global production networks and the analysis of economic development. Review of International Political Economy, 9: 436-464.

Hensmans, M. 2003. Social movement organizations: A metaphor for strategic actors in institutional fields. Organization Studies, 24: 355-382.

Hillman, A. J., \& Keim, G. D. 2001. Shareholder value, stakeholder management, and social issues: what's the bottom line? Strategic Management Journal, 22: 125 - 139.

Hirsch, P. M. 1975. Organizational effectiveness and the institutional environment. Administrative Science Quarterly, 20: 327-344.

Hirst, P., \& Thompson, G. 1996. Globalization in question. Malden, MA: Blackwell.

Hoffman, A. J. 1999. Institutional evolution and change: environmentalism and the U.S. chemical industry. Academy of Management Journal, 42: 351-371.

Hopkins, T., \& Wallerstein, I. 1977. Patterns of development of the modern world-system. Review of International Political Economy, 1: 111-145.

Hymer, S. 1972. The multinational corporation and the law of uneven development. In J. Bhagwati (Ed.), Economics and world order from the 1970s to the 1990s: 113-140. New York: Collier-MacMillan.

Hymer, S. 1976. The international operations of national firms. Cambridge, MA: MIT Press. Hymer, S. 1979. The multinational corporation and the international division of labour. In R. B. Cohen, N. Felton, J. van Liere, \& M. Nkosi (Eds.), The multinational corporation: A radical approach. Papers by Stephen Herbert Hymer: 140-164. Cambridge: Cambridge University Press.

Jessop, B. 2005. Gramsci as a spatial theorist. Critical Review of International Social and Political Philosophy, 8(4): 421-437.

Kaplinsky, R. 2000. Spreading the gains from globalisation: What can be learned from value chain analysis? Institute for Development Studies, Sussex University.

Kaplinsky, R. 2005. Globalization, poverty and inequality: Between a rock and a hard place. Cambridge: Polity.

Keohane, R. O. 1984. After hegemony: Cooperation and discord in the world political economy. Princeton: Princeton University Press.

Klein, N. 2000. No Logo. London: Flamingo.

Kletzer, L. 2001. Job loss from imports: measuring the costs. Washington DC: Institute for International Economics.

Kobrin, S. J. 1987. Testing the bargaining hypothesis in the manufacturing sector in developing countries. International Organization, 41: 609-638.

Kolk, A. 2005. Corporate social responsibility in the coffee sector: the dynamics of MNC responses and code development. European Management Journal, 23: 228-236.

Korten, D. C. 1995. When corporations rule the world. West Hartford, Conn.: Kumarian Press.

Kostova, T., \& Roth, K. 2002. Adoption of an organizational practice by the subsidiaries of the MNC: Institutional and relational effects. Academy of Management Journal, 45: 215233.

Kostova, T., \& Zaheer, S. 1999. Organizational legitimacy under conditions of complexity: the case of the multinational enterprise. Academy of Management Review, 24: 64-81.

Kotabe, M. 1992. Global sourcing strategy: $R \& D$, manufacturing, and marketing Interfaces. Westport, CT: Quorum Books. 
Kotabe, M., \& Swan, K. S. 1994. Offshore sourcing: Reaction, maturation and consolidation of US multinationals. Journal of International Business Studies, 25: 115-140.

Laclau, E., \& Mouffe, C. 1985. Hegemony and socialist strategy: Toward a radical democratic politics. New York: Verso.

Lash, S., \& Urry, J. 1994. Economies of signs and space. London: Sage.

Lazonick, W., \& O'Sullivan, M. 2000. Maximizing shareholder value: a new ideology for corporate governance. Economy and Society, 29 (1): 13 - 35.

Levy, D. L. 1997. Lean production in an international supply chain. Sloan Management Review, 38 (2): 94-102.

Levy, D. L. 2005. Offshoring in the new global political economy. Journal of Management Studies, 42: 685-693.

Levy, D. L., \& Egan, D. 2003. A neo-Gramscian approach to corporate political strategy: Conflict and accommodation in the climate change negotiations. Journal of Management Studies, 40: 803-830.

Levy, D. L., \& Kolk, A. 2002. Strategic responses to global climate change: Conflicting pressures on multinationals in the oil industry. Business and Politics, 4: 275-300.

Levy, D. L., \& Newell, P. J. 2005. The business of global environmental governance. Cambridge, MA: MIT Press.

Levy, D. L., \& Prakesh, A. 2003. Bargains old and new: Multinationals in international governance. Business and Politics, 5: 131-151.

Levy, D. L., \& Rothenberg, S. 2002. Heterogeneity and change in environmental strategy: technological and political responses to climate change in the automobile industry. In A. Hoffman, \& M. Ventresca (Eds.), Organizations, policy and the natural environment: Institutional and strategic perspectives: 173-193. Stanford: Stanford University Press.

Levy, D. L., Willmott, H., \& Alvesson, M. 2003. Critical approaches to strategic management. In M. Alvesson, \& H. Willmott (Eds.), Studying management critically, 2nd edition: 92110. Newbury Park, CA: Sage.

Lichtenstein, N. (Ed.). 2006. Wal-Mart: The face of twenty-first century capitalism. New York: The New Press.

Lounsbury, M., \& Ventresca, M. 2002. Social Structure and Organizations Revisited. New York: JAI Press.

Lounsbury, M., Ventresca, M. J., \& Hirsch, P. M. 2003. Social movements, field frames and industry emergence: a cultural-political perspective on US recycling. SocioEconomic Review, 1: 71-104.

Maguire, S., \& Hardy, C. 2006. The emergence of new global institutions: A discursive perspective. Organization Studies, 27: 7-29.

Maguire, S., Hardy, C., \& Lawrence, T. B. 2004. Institutional entrepreneurship in emerging fields: HIV/AIDS treatment advocacy in Canada. Academy of Management Journal, 47: 657-679.

McAdam, D., McCarthy, J., \& Zald, M. 1996. Comparative perspectives on social movements. New York: Cambridge University Press.

McAdam, D., \& Scott, R. W. 2005. Organizations and movements. In G. F. Davis, D. McAdam, R. W. Scott, \& M. Zald (Eds.), Social movements and organization theory: 4-40. Cambridge, UK: Cambridge University Press.

McChesney, R. W. 2000. Rich media, poor democracy: Communication politics in dubious times. Champaign, IL: University of Illinois Press. 
Mintzberg, H., Ahlstrand, B., \& Lampel, J. 1998. Strategy safari: A guided tour through the wilds of strategic management. New York: The Free Press.

Morgan, G. 2001. Transnational communities and business systems. Global Networks: A Journal of Transnational Affairs, 1: 113-130.

Mumby, D. K. 1997. The problem of hegemony: rereading Gramsci for organizational communication studies. Western Journal of Communication, 61: 343-375.

Murphy, C. N. 1998. Understanding IR: understanding Gramsci. Review of International Studies, 24: 417-425.

Narula, R., \& Dunning, J. H. 2000. Industrial development, globalization, and multinational enterprises. Oxford Development Studies, 28: 141-167.

Ohmae, K. 1991. The borderless world: Power and strategy in the interlinked economy. New York: Harper and Row.

Olds, K., \& Thrift, N. 2005. Cultures on the brink: reengineering the soul of capitalism - on a global scale. In A. Ong, \& S. J. Collier (Eds.), Global assemblages: Technology, politics, and ethics as anthropological problems: 270-290. Malden, MA: Blackwell.

Palan, R., \& Abbott, J. 1996. State strategies in a global political economy. London: Cassel.

Pauly, L. W., \& Reich, S. 1997. National structures and multinational corporate behavior: enduring differences in an age of globalization. International Organization, 51: 1-30.

Penrose, E. T. 1959. The theory of the growth of the firm. Oxford: Oxford University Press.

Pfeffer, J., \& Salancik, G. R. 1978. The external control of organizations: A resource dependence perspective. New York: Harper and Row.

Pitelis, C. 2006. Stephen Herbert Hymer and/on the (theory of the) MNE and international business. International Business Review, 15: 103-110.

Piven, F. F., \& Cloward, R. A. 1997. Breaking the social compact: The globalization hoax. New York: The New Press.

Porter, M. E. 1985. Competitive advantage: Creating and sustaining superior performance. New York: Free Press.

Porter, M. E. 1990. The competitive advantage of nations. New York: Free Press.

Powell, W. W., \& DiMaggio, P. J. (Eds.). 1991. The new institutionalism in organizational analysis. Chicago: University of Chicago Press.

Prahalad, C. K., \& Doz, Y. L. 1987. The multinational mission: balancing local demands and global vision. New York: Free Press.

Prakash, A., \& Hart, J. (Eds.). 1999. Globalization and governance. London: Routledge.

Przeworski, A., \& Wallerstein, M. 1982. The structure of class conflict in democratic capitalist societies. American Political Science Review, 76: 215-238.

Radin, T. J. 2004. The effectiveness of global codes of conduct: role models that make sense. Business and Society Review, 109: 415-447.

Ramamurti, R. 2001. The obsolescing 'Bargaining Model'? MNC-Host developing country relations revisited. Journal of International Business Studies, 32: 23-39.

Rao, H., Morrill, C., \& Zald, M. N. 2000. Power plays: how social movements and collective action create new organizational forms. Research in Organizational Behaviour, 22: 239-282.

Ruigrok, W., \& van Tulder, R. 1995. The logic of international restructuring. London: Routledge.

Salomon, R., \& Shaver, J. M. 2005. Export and domestic sales: their interrelationship and determinants. Strategic Management Journal, 26: 855 - 871. 
Samuelson, P. A. 2004. Where Ricardo and Mill rebut and confirm arguments of mainstream economists supporting globalization. Journal of Economic Perspectives, 18 (3): 135146.

Sanbonmatsu, J. 2004. The postmodern prince: Critical theory, left strategy, and the making of a new political subject. New York: Monthly Review Press.

Sassen, S. 1996. Losing control? Sovereignty in an age of globalization. New York: Columbia University Press.

Schurman, R. 2004. Fighting "Frankenfoods": Industry opportunity structures and the efficacy of the anti-biotech movement in Western Europe. Social Problems, 51: 243-268.

Scott, W. R., \& Meyer, J. W. (Eds.). 1994. Institutional environments and organizations. Thousand Oaks, CA: Sage.

Sell, S. K. 2002. Private power, public law. Cambridge: Cambridge University Press.

Sell, S. K., \& Prakash, A. 2004. Using ideas strategically: The contest between business and NGO networks in intellectual property rights. International Studies Quarterly, 48: 143175.

Selsky, J. W., Spicer, A., \& Teicher, J. 2003. 'Totally Un-Australian!': discursive and institutional interplay in the Melbourne port dispute of 1997-98. Journal of Management Studies, 40: 1729-1760.

Seo, M.-G., \& Creed, W. E. D. 2002. Institutional contradictions, praxis and institutional change: A dialectical perspective. Academy of Management Review, 27: 222-247.

Shaver, J. M., \& Flyer, F. 2000. Agglomeration economies, firm heterogeneity, and foreign direct investment in the United States. Strategic Management Journal, 21: 1175 - 1193.

Sklair, L. 1997. Social movements for global capitalism: The transnational capitalist class in action. Review of International Political Economy, 4: 514-538.

Sklair, L. 1998. Transnational corporations as political actors. New Political Economy, 3 (2): 284-287.

Stopford, J., \& Strange, S. 1991. Rival states, rival firms. Cambridge: Cambridge University Press.

Strange, R., \& Newton, J. 2006. Stephen Hymer and the externalization of production. International Business Review, 15: 180-193.

Strange, S. 1996. The retreat of the state: The diffusion of power in the world economy. Cambridge: Cambridge University Press.

Swamidass, P. M., \& Kotabe, M. 1993. Component sourcing strategies of multinationals: An empirical study of European and Japanese multinationals. Journal of International Business Studies, 24: 81-100.

Swann, C. 2004. More offshore jobs mean higher US employment, say economists, Financial Times: 8. London.

Talbot, J. M. 2004. Grounds for agreement: The political economy of the coffee commodity chain. Lanham, MD: Rowman and Littlefield.

Teece, D. J. 1986. Transaction cost economics and the multinational enterprise. Journal of Economic Behavior and Organization, 7: 21-45.

Teece, D. J. 2006. Reflections on the Hymer thesis and the multinational enterprise. International Business Review, 15: 124-139.

Teece, D. J., Pisano, G., \& Shuen, A. 1997. Dynamic capabilities and strategic management. Strategic Management Journal, 18: 509-533. 
Teegen, H., Doh, J. P., \& Vachani, S. 2004. The importance of nongovernmental organizations in global governance and value creation: An international business research agenda. Journal of International Business Studies, 35: 463-483.

Tulder, R. v., \& Kolk, A. 2001. Multinationality and corporate ethics: Codes of conduct in the sporting goods industry. Journal of International Business Studies, 32: 267-283.

Urry, J. 2000. Sociology beyond societies. London: Routledge.

Utting, P. (Ed.). 2002. Voluntary approaches to corporate responsibility. Geneva: United Nations Non-Governmental Liaison Service.

Vachani, S., \& Smith, C. N. 2004. Socially responsible pricing: Lessons from the pricing of AIDS drugs in developing countries. California Management Review, 47 (1): 117-144.

van der Pijl, K. 1998. Transnational classes and international relations. London: Routledge.

van Tulder, R., \& Kolk, A. 2003. Multinationality and corporate ethics: Codes of conduct in the sporting goods industry. Journal of International Business Studies, 32: 267-283.

Vernon, R. 1971. Sovereignty at bay: The multinational spread of U.S. enterprises. New York: Basic Books.

Vernon, R. 1977. Storm over the multinationals. Cambridge, Mass.: Harvard University Press.

von Mises, L. 1985. Liberalism in the classical tradition. Irvington, NY: Foundation for Economic Education.

Wallerstein, I. 2004. World-Systems Analysis: An Introduction. Durham, NC: Duke University Press.

Wesselius, E. 2002. Behind GATS 2000: Corporate Power at Work. Amsterdam, The Netherlands: Transnational Institute briefing Series No.6, (www.tni.org).

Westney, E. 1993. Institutionalization theory and the multinational corporation. In S. Ghoshal, \& E. Westney (Eds.), Organization theory and the multinational corporation: 53-76. New York: St. Martin's Press.

Williams, K. 2000. From shareholder value to present-day capitalism. Economy and Society, 29: $1-12$.

Williams, M., \& Ford, L. 1999. The World Trade Organization, social movements and global environmental management. Journal of Environmental Politics, 8 (1): 268-289. 


\section{Acknowledgements}

I am grateful to Jean Boddewyn, Bobby Banerjee, Peter Dicken, Jonathan Doh, Steve Kobrin, Peter Newell, Hugh Willmott, Henry Yeung, and the participants in the 2006 Research Colloquium on Corporate Political Activities in an Internationalizing Economy, Free University of Amsterdam, for providing insightful comments on earlier drafts of this paper. I also thank guest editor Gavin Jack and two anonymous referees for their constructive guidance. Any errors or omissions are mine alone.

\section{FOOTNOTES}

${ }^{1}$ Followers of the Austrian school of economists, most notably Ludwig von Mises (1985) and Friedrich von Hayek (1944), would also decry the distorting impact of political intervention on markets, though drawing very different implications. While Austrian school economists advocate the necessity of isolating markets from politics, this paper suggests the impossibility of doing so.

${ }^{2}$ Antonio Gramsci (1891-1937) was a radical Italian political theorist, journalist, and activist. He wrote The Prison Notebooks (1971) while imprisoned by Italy's Fascist government from 1926 to 1934.

${ }^{3}$ The Trans-Atlantic Business Dialogue is a network of more than 150 major North American and European firms that works with government officials to reduce barriers to economic integration and trade. 